\title{
Cross-functional executive involvement and worker involvement in lean manufacturing and sustainability alignment
}

\author{
Annachiara Longoni \\ ESADE Business School, Ramon Llull University, Barcelona, Spain, \\ and \\ Raffaella Cagliano \\ School of Management, Politecnico di Milano, Milano, Italy
}

\begin{abstract}
Purpose: Lean manufacturing has been demonstrated to increase operations and economic performance, but its alignment with environmental and social sustainability is unclear. Our primary goal is to understand how cross-functional executive involvement and worker involvement, in the formulation and implementation of operations strategy, support the strategic alignment of lean manufacturing and sustainability.
\end{abstract}

Methodology: An inductive case study methodology was employed. Such theoretical elaboration is appropriate when extending existing theory (i.e., operations strategy theory and sustainability development theory). Evidence was drawn from 10 crossindustry case studies. Within and cross-case analyses were performed.

Findings: The results demonstrate that cross-functional executive involvement and worker involvement positively affect the strategic alignment of the lean manufacturing statement and bundles (just-in-time, total quality management, total preventive maintenance, and human resources management) with environmental and social goals and practices. Specifically, the study reveals the impact of cross-functional executive involvement on the formulation of lean manufacturing aligned with environmental and social sustainability. Worker involvement positively affects the actual implementation of lean manufacturing that is aligned with environmental and social sustainability.

Practical implications: This research provides guidance to practitioners regarding how different organizational models lead to different levels of lean manufacturing and sustainability strategic alignment and performance.

Originality: This research contributes to the operations strategy literature and the sustainability development literature, providing evidence regarding the mechanisms supporting the strategic alignment of lean manufacturing and sustainability.

Keywords: lean manufacturing, sustainability, organizational model, strategic alignment

Article classification: research paper

Post-print version of the paper:

Longoni, A., \& Cagliano, R. (2015). Cross-functional executive involvement and worker involvement in lean manufacturing and sustainability alignment. International Journal of Operations \& Production Management. International Journal of Operations \& Production Management, Vol. 35 No. 9, pp. 1332-1358 - DOI 10.1108/IJOPM-02-2015-0113

Author's post-print released with a Creative Commons Attribution Non-Commercial No Derivatives License 


\section{Introduction}

Sustainability is an increasingly essential element of most company strategies (McKinsey, 2013); however, the formulation and implementation of operations strategies that embrace sustainability remain open issues. Specifically, companies encounter difficulties in aligning operations strategies with sustainability in terms of environmental and social goals and practices. For example, the alignment of a traditional lean manufacturing operations system with environmental and social sustainability might be challenging (King and Lennox, 2001; Hasle et al., 2012). At the operations level, sustainability means developing processes that are more efficient and less costly in terms of energy and resource use (environmental sustainability), as well as maintaining adequate standards for worker well-being (social sustainability) (Epstein, 2008).

Academics and managers widely agree that lean manufacturing represents a powerful tool for improving operational and economic performance (e.g., Shah and Ward, 2003). However, this positive view of lean manufacturing outcomes has recently been heavily debated, with many researchers questioning the lean manufacturing's potentially negative impact on environmental and social sustainability (e.g., King and Lenox, 2001; Hasle et al., 2012; Longoni et al., 2013). Similar discussions among practitioners are also ongoing. For example, dozens of groups on social networks such as LinkedIn discuss environmental and social impacts in a lean manufacturing environment.

The aim of this study is to understand whether and how lean manufacturing can be aligned with environmental and social sustainability. Specifically, we focus on the role played by the organizational model employed to formulate and implement a company's environmental and social sustainability goals in an operations setting that is characterized by lean manufacturing adoption. Prior research in operations strategy suggests that cross-functional executive involvement and worker involvement positively affect the alignment of strategic goals and behaviors at different hierarchical levels and within functions (Joshi et al., 2003; Papke-Shilds and Malhotra, 2001; Xu et al., 2006). Moreover, a number of studies have reported evidence regarding the role of organizational variables in fostering the internal and external consistency of sustainability strategies across the organization (Epstein, 2008).

The contribution of this paper is twofold. The primary aim is to understand the 
role of the organizational model in supporting strategic alignment between lean manufacturing and environmental and social sustainability. This effort is of substantial importance for companies by providing guidance on how strategic alignment could be pursued. Second, we also assess whether the strategic alignment of lean manufacturing and environmental and social sustainability is possible.

In the following section, we present the extant literature on lean manufacturing and its relation with environmental and social sustainability, as well as the research on strategic alignment in operations strategies and the role of the organizational model. Then, we describe our methodology. Our results are presented and discussed in detail. Then, we discuss managerial implications and theoretical contributions and conclude by highlighting the limitations of the study and future research directions.

\section{Literature review and research questions}

\subsection{Strategic alignment of lean manufacturing and sustainability}

Lean manufacturing aims to streamline the flow of production while continually seeking to reduce the resources required to produce a given set of products. From a strategic point of view, the lean manufacturing statement (i.e., the description of the lean manufacturing strategy in terms of priorities), rather than setting a goal of a specific level of leanness, is based on continuous improvement in waste reduction (Womack et al., 1990). Lean manufacturing is a combination of synergistic and mutually reinforcing practices, which have been grouped into four complementary bundles of practices: just-in-time (JIT) manufacturing, total quality management (TQM), total preventive maintenance (TPM), and human resource management (HRM) (Shah and Ward, 2003).

The relationship between lean manufacturing and environmental and social sustainability is currently under discussion, and both synergies and trade-offs between these factors have been suggested (King and Lenox, 2001; Hasle et al., 2012; Longoni et al., 2013). Companies that simultaneously adopt lean manufacturing and pursue environmental and social sustainability need to understand how to align these efforts to avoid contradictory effects.

Sustainability development has been studied mainly in terms of content, goals, and practices, rather than in terms of deployment process. Therefore, companies are struggling to understand how to deploy their sustainability goals and practices in their business processes. 
Concerning operations, such deployment process consists of the formulation and implementation of an operations strategy which translates the company's goals into tasks-goals and practices - that the operations should perform (Ferdows and de Meyer, 1990; Joshi et al., 2003).

Concerning the operations strategy formulation, the literature distinguishes between two types of alignment: vertical alignment (or external fit) and horizontal alignment (or internal fit) (Kathuria et al., 2007). To be successful, the operations strategy should be aligned vertically, that is, ensuring consistency between the company's strategic goals and the operations strategy, and horizontally, that is, ensuring consistency between the operations' goals (i.e., cost, quality, delivery, and flexibility) and the operations' practices (Skinner, 1974). In this study, vertical alignment refers to the alignment of the company's environmental and social sustainability goals and the lean manufacturing statement. Our research is focused on understanding how lean manufacturing strategies can be aligned with company environmental and social sustainability goals. This is important because, while lean manufacturing potentially produces an operational and cultural environment that is highly conducive to waste minimization and pollution prevention, it does not explicitly incorporate environmental goals. Therefore, trade-offs might emerge when a firm simultaneously pursues lean manufacturing and environmental goals. Aligning the lean manufacturing statement with social sustainability goals might be inherent in the lean HRM-related philosophy, which is often referred to as "respect-for-humanity" (Womack, et al., 1990). However, the alignment of the overall lean manufacturing statement with social goals is not always obvious, especially with respect to lean bundles other than HRM.

In this study, horizontal alignment refers to the alignment between each lean manufacturing bundle (i.e., set of practices) and the operations' environmental and social goals, along with the alignment of each lean manufacturing bundle with environmental and social practices within operations. Even if horizontal alignment may appear to be consequent to vertical alignment, previous research has shown that this is not necessarily the case (e.g., Gratton and Truss, 2003). Companies achieving high levels of vertical alignment may not present horizontal alignment and vice versa because the two dimensions operate at different levels. Vertical alignment is concerned with whether or not the operations strategy statement supports the company's strategic goals. Instead, horizontal alignment is concerned with the degree of internal coherence and consistency in the operations strategy (i.e., operations' goals and practices). 
Horizontal alignment is necessary to avoid contradictory activities within operations (i.e., some sustainability-oriented practices in operations have positive effects on sustainability performance, while other lean manufacturing practices have negative effects). Tables 1 and 2 summarize the trade-offs and synergies between lean manufacturing bundles and environmental and social sustainability that have been identified in the literature.

\section{[Please insert Table 1 here]}

[Please insert Table 2 here]

To avoid negative effects of lean manufacturing on environmental and social sustainability and also to enhance possible positive effects, each lean manufacturing bundle must be revised to consider the impact on the company's environmental and social goals. Several authors suggest that the impacts of lean manufacturing depend on management decisions regarding its design and implementation (Conti et al., 2006; de Treville and Antonakis, 2006).

Moreover, environmental and social sustainability are generally pursued through specific practices (e.g., Angel and Klassen, 1999). Lean manufacturing can also have an impact on environmental and social sustainability practices. Concerning environmental practices, several authors suggest that companies can use lean manufacturing as a catalyst for improving environmental practices (e.g., pollution prevention practices) because “lean” and "green” have overlapping practices and elements (Dües et al., 2013). Concerning social sustainability, the TQM and TPM bundles are related to social practices. In particular, studies propose a parallel between quality and safety principles (Herrero et al., 2002). As for TQM, the primary goal for safety practices is "zero accidents," and the primary goal for quality is "zero defects." Moreover, to improve both safety and quality performance, companies need to analyze relevant incidents or events using statistical procedures. Both safety and quality policies must be well documented and precise, require the full participation of workers, and are based on the principle that "all accidents and injuries/not conformities could have been prevented” (Herrero et al., 2002). Despite this, social practices are not explicitly part of lean manufacturing. Therefore, aligning the two requires intentional action.

Figure 1 summarizes the elements of the vertical and horizontal alignment between lean manufacturing and environmental and social sustainability. 
Figure 1: Sustainability strategic alignment

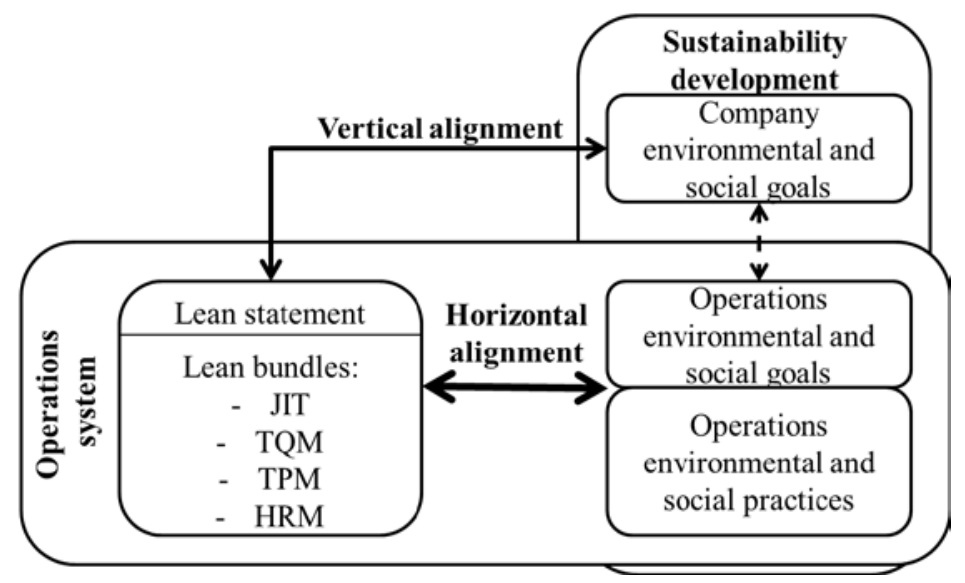

Finally, strategic alignment is also important in operations strategy implementation (or action), that is, action alignment (Joshi et al., 2003). Despite this, the question of what actually occurs after the operations strategy formulation has received scant attention (Kathuria et al., 2007). In this study, action alignment is studied in terms of the degree to which the strategic alignment of lean manufacturing with environmental and social sustainability is put into practice in day-to-day activities. The alignment of lean manufacturing with environmental and social sustainability is transformed into action when this becomes the new routine, and the old way of working is completely replaced.

\subsection{The role of cross-functional executive involvement and worker involvement}

Research on operations strategies highlights that the organizational model adopted during the operations strategy formulation and implementation can play an important role in achieving strategic alignment (Joshi et al., 2003; Papke-Shilds and Malhotra, 2001). Similarly, research on the development of environmental and social sustainability suggests that the organizational model is key to aligning operations strategies with the company’s sustainability goals (Epstein, 2008).

Specifically, the operations management literature demonstrates that cross-functional decision-making processes are important in the vertical and horizontal alignment of operations strategies with the company's goals (Papke-Shilds and Malhotra, 2001). This becomes especially crucial with respect to the alignment of the operations strategy and the company’s sustainability goals (Maxwell al., 1998; Russo and Harrison, 2005). Specifically, the literature suggests that coordination and communication between 
operations executives and sustainability manager $(s)^{1}$ in the decision-making process is necessary to vertically and horizontally align operations strategies with the company's environmental and social sustainability goals (Russo and Harrison, 2005). Accordingly, we suggest that the involvement of operations executives in the formulation of the company's sustainability goals will provide operations with a clearer picture of the strategic direction of the company and the associated requirements that might affect the formulation of the operations strategy (i.e., the lean manufacturing system). Moreover, sustainability manager(s) must influence the decision-making process during the formulation of the operations strategy (i.e., the lean manufacturing system) to guarantee that "their self-interests", in this case, environmental and social sustainability goals, are pursued and not overcome by other operations’ priorities, such as cost, delivery, quality, and flexibility (Sapienza and Korsgaard, 1996).

While cross-functional executive involvement provides the framework that supports the action alignment of the operations strategy and the company's sustainability goals, the literature also suggests that in the absence of broader worker involvement the actual degree of action alignment of the operations strategy with environmental and social sustainability may be limited

(Russo and Harrison, 2005). The development of the action alignment requires increased operations worker awareness regarding environmental and social sustainability goals and the development of their knowledge and skills (Epstein, 2008). Furthermore, broader worker participation in important discussions regarding possible environmental and social sustainability issues, rather than the involvement of operations executives and sustainability manager(s) only, is often considered crucial to successful implementation (Hanna et al., 2000). Therefore, the following research questions are formulated:

RQ1. How do cross-functional executive involvement and worker involvement affect the strategic alignment of lean manufacturing with environmental and social sustainability?

\footnotetext{
1 We use "sustainability manager(s)" to represent the senior individual(s) responsible for environmental and social tasks. No generally accepted job title exists for these roles (e.g., head of sustainability, health and safety compliance manager, environmental manager, EHS [Environment, Health, and Safety] manager), but this term is sufficiently flexible to create a shared meaning among practitioners and academics.
} 
RQ1a. How do cross-functional executive involvement and worker involvement affect the vertical and horizontal alignment of lean manufacturing with environmental and social sustainability?

$R Q 1 b$. How do cross-functional executive involvement and worker involvement affect the action alignment of lean manufacturing with environmental and social sustainability?

\section{Methodology}

To ground our theoretical insights, we employed an inductive case study methodology to address the research questions. Such theoretical elaboration is appropriate when previous research provides a starting point for a new inductive study (Maitlis, 2005). We sought to extend existing theory on operations strategies and sustainability development.

\section{$\underline{\text { Sample }}$}

To provide content validity and reliability, ten case studies were theoretically selected (Eisenhardt, 1989), and the sample population was defined by including only companies adopting lean manufacturing and having environmental and social sustainability goals at both the company level and operations level. The sample population was defined based on secondary data. First, we identified leading companies in the adoption of lean manufacturing based on winners of lean manufacturing awards and those listed among lean adopters in secondary sources. We then confirmed this information by visiting the plants and during interviews (see Appendix A). Second, among these identified companies, the population was limited to those companies having environmental and social sustainability goals as assessed by analyzing each company's sustainability reports. We identified companies defining goals at the company level and operations level (i.e., energy and resource consumption reduction goals in production; health and safety goals in production; progress on environmental and social issues throughout the supply chain; the design of environmentally friendly and healthier products and production goals). We confirmed this information during the interviews (see Appendix B).

Then, we selected a set of ten companies that were different in terms of industries and firm sizes and that-for geographic reasons-were accessible by the researchers. The main information about the sample is provided in Table 3. 


\section{$\underline{\text { Data collection }}$}

Given our focus, the level of analysis used in this study is the operations function. Multiple case studies with multiple respondents were conducted. Specifically, 36 interviews were conducted on an average of 3 or 4 people in each company. Data were collected through structured questionnaires and semi-structured interviews. The structured questionnaire was completed by email before the semi-structured interview in order to gather information on established constructs such as environmental and social sustainability goals, the adoption of lean manufacturing, and sustainability practices. Each item was measured on a 5-point Likert scale. In this way, we had more time during semi-structured interviews to collect information about less established aspects such as the sustainability deployment process (formulation and implementation) and the relationship between lean manufacturing and environmental and social sustainability. The semi-structured interviews lasted for approximately 60 90 minutes. The semi-structured interviews were recorded, and additional notes were taken regarding particularly interesting evidence. One production site was visited for each company.

By collecting data through multiple respondents, we were able to triangulate information. Information collected through the structured questionnaire provided by different respondents was generally similar and presented no more than one Likert point difference in their answers. The average of respondents' answers was used to measure constructs. Few discrepancies were shown during semi-structured interviews. If there was any discrepancy, we considered the information reliable if provided by more than half of the respondents.

\section{$\underline{\text { Data coding and analysis }}$}

The data analysis consisted of two steps: within-case analysis and cross-case analysis (Eisenhardt, 1989). Within-case analysis allowed us to finalize the codebook and establish the patterns of relationships within companies.

First, cross-functional executive involvement and worker involvement were coded and assessed as described in Table 4. Data to assess the constructs were provided by the semi-structured interviews and internal documents. 


\section{[Please insert Table 4]}

Then, the strategic alignment between lean manufacturing and environmental and social sustainability was coded and assessed. Data were provided by the semi-structured interviews and internal documents and then triangulated with the facility visit information. The strategic alignment assessment was conducted according to Venkatraman's (1989) suggestion regarding the measure of fit/alignment as matching. Therefore, strategic alignment was assessed using dichotomous variables (1=alignment; $0=$ not alignment) based on the items described in Table 5 and constituting an index (as the sum of the different dimensions).

\section{[Please insert Table 5 here]}

This assessment was then tested using the external criterion (Venkatraman, 1989) of actual environmental and social sustainability performance achieved. Sustainability performance values were coded as described in Table 6 . The information used to assess sustainability performance was collected from the company's sustainability and financial reports and was confirmed by the structured questionnaire.

\section{[Please insert Tables 6]}

Finally, to perform cross-case analyses, companies were grouped based on their levels of cross-functional executive involvement and worker involvement.

\section{Results}

As shown in Tables 7 and 8, the results indicate that three groups can be identified based on the level of cross-functional executive involvement and worker involvement. Tables 9, 10, and 11 show that the organizational models adopted lead to different levels of strategic alignment and consequently different performance levels (see Table 12).

[Please insert Tables 7, 8, 9, 10,11, 12]

The first group of companies employs an Advanced organizational model characterized by high cross-functional executive involvement and worker involvement (Complex Food, Goods, Medium Milk, and Systems). This group of companies exhibits higher levels of vertical, horizontal, and action alignment between lean manufacturing and environmental and social sustainability. Greater strategic alignment results in an above average overall level of sustainability performance. The second group of companies has a Traditional organizational model characterized by low crossfunctional executive involvement and worker involvement (Big Milk, Furniture, Lamps, 
and Veggie). The levels of vertical, horizontal, and action alignment between lean manufacturing and environmental and social sustainability exhibited by this group are the lowest in the sample. Consequently, the overall level of sustainability performance realized by this group is below average.

Finally, Accessory and Small Pasta do not fit into the two main groups. They are both characterized by a Transitional organizational model that shares similarities with the two main groups but also exhibits differences. Both companies only recently began to focus on sustainability (Small Pasta in 2007 and Accessory in 2009) and are still in the process of defining their sustainability goals. At Accessory, cross-functional executive involvement is quite high, particularly concerning the influence of the sustainability manager in decision making regarding operations strategy. However, operations executives are seldom involved in formulating the company's sustainability goals and practices. Moreover, the company has high levels of worker involvement, despite the absence of formal processes to allow worker participation. Accessory exhibits high levels of vertical and action alignment but low horizontal alignment. At Small Pasta, cross-functional executive involvement is quite high, but the involvement of operations executives is higher than the influence of the sustainability manager on the decision-making process. Worker involvement is developed through communication and the informal participation of workers in sustainability development. In this case, vertical and action alignment are low despite high horizontal alignment. Currently, Accessory exhibits better overall sustainability performance than Small Pasta.

\section{Discussion and implications}

The results show that companies characterized by different organizational models achieve different levels of strategic alignment between lean manufacturing and environmental and social sustainability. Companies characterized by an Advanced organizational model are able to enhance the positive links between lean manufacturing and environmental and social sustainability (Longoni et al., 2013) and avoid possible negative links (Rottenberg, 2001).

Concerning vertical alignment, companies with high levels of cross-functional executive involvement, especially a high degree of influence by the sustainability manager(s) (i.e., companies with the Advanced organizational model and Accessory), 
exhibit the highest level of vertical alignment between the company's sustainability goals and the lean manufacturing statement. In fact, the sustainability manager(s) exert significant influence on decision making related to the formulation of operations strategy. Also, the involvement of the operations executive in the formulation of sustainability goals makes sustainability acceptable and a goal to be pursued within operations and the lean manufacturing strategy. Therefore, cross-functional executive involvement enables a cross-functional decision-making process that positively affects the vertical alignment (Russo and Harrison, 2005).

The result is that companies with high levels of cross-functional executive involvement have formulated a specific lean manufacturing statement that includes environmental and social sustainability goals, enlarging the lean statement concerning waste reduction to environmental aspects, as well as expanding the process-centered improvement focus to environmental and social aspects (King and Lenox, 2001; Sawhney et al., 2007). For example, at Goods, the lean manufacturing system, called the Goods Manufacturing Excellence Program, includes both environmental and social sustainability goals in its statement; this new production system must contribute to sustainability. Systems began developing its lean system ten years ago, based on nine elements that involve lean manufacturing principles, such as Kaizen, Leadership, Quality, and so on. Since 2006, environmental and social sustainability have been two of the nine foundational principles of this integrated lean system. Similarly, among the ten pillars defining Accessory's lean manufacturing statement, one is dedicated to environmental management and one to worker health and safety.

Conversely, when cross-functional executive involvement is low, and the sustainability manager(s) have little influence (i.e., in companies with the Traditional organizational model), traditional operations’ goals are predominant, and the lean manufacturing statement is not (re)formulated according to sustainability goals.

Therefore, we developed the first research proposition:

\section{P1. Cross-functional executive involvement facilitates the vertical alignment of} the lean manufacturing statement and the company's environmental and social sustainability goals.

Moreover, referring primarily to the Accessory case, where the sustainability manager(s) influence is higher than the operations executive involvement and vertical alignment is achieved, we suggest that: 


\section{P1a. The influence of the sustainability manager(s) plays a more important role}

compared to the involvement of the operations executives in fostering vertical alignment.

Concerning horizontal alignment between lean bundles and the operations' sustainability goals, lean bundles are constantly reviewed according to environmental and social goals, thanks to cross-functional executive involvement, especially the involvement of operations executives in the formulation of the company's sustainability goals (i.e., in companies with the Advanced organizational model and Small Pasta). Although it may seem that vertical alignment leads easily to horizontal alignment due to the lean manufacturing statement's alignment with the company's sustainability goals, this is not necessarily the case. In our sample, not all companies that achieve vertical alignment also present horizontal alignment (i.e., Accessory). On the other hand, horizontal alignment is also sometimes present when vertical alignment is not achieved (i.e., Small Pasta).

Concerning horizontal alignment, the involvement of operations executives allows them to be committed to sustainability goals in operations and to understand the need to effectively include them in the operations strategy. Moreover, their involvement leads to the identification of the practices available to satisfy sustainability goals in operations and the refusal of practices with negative effects. In some cases, lean manufacturing might have positive effects on environmental and social sustainability (Longoni et al., 2014); in other cases, it might have negative effects (Martínez-Jurado and Moyano-Fuentes, 2013). Companies characterized by an Advanced organizational model experienced trade-offs when adopting lean manufacturing together with sustainability goals. However, their cross-functional executive involvement allows these companies to formulate lean manufacturing bundles so that win-win opportunities are exploited, while win-lose situations are minimized as much as possible. Regarding the specific bundles, we first notice that higher cross-functional executive involvement, especially involvement of operations executives, allows the identification of possible synergies between lean HRM practices (e.g., involvement and training) and environmental and social goals (Rothenberg et al., 2001). Specifically, these firms implement training related to environmental and social 
issues to increase worker awareness. Moreover, they enhance worker participation in collecting ideas and suggestions regarding sustainability.

Concerning JIT, the involvement of operations executives in the formulation of sustainability goals encourages them to investigate the negative effects that JIT might have on environmental and social performance and invest effort in revising certain JIT practices. For example, operations executives at Systems and Goods analyzed the impact of JIT deliveries and decided to negotiate JIT deliveries with only suppliers located near the plant. Similarly, Systems takes into account the health and safety issues involved in JIT adoption; in particular, the company designed ergonomic and comfortable workplaces; furthermore, the Takt Time (TT) is defined based on worker fatigue levels and breaks to provide the necessary flexibility to preserve worker health.

Moreover, TQM and TPM practices have been revised by companies with an Advanced organizational model to further exploit their positive effect on environmental and social performance (Herrero et al., 2002). For example, at Systems, operations executives designed Value Stream Mapping to identify and address health and safety or environmental issues, TQM is used to monitor environmental and social indicators, and TPM is designed to prevent energy losses and material waste. Similarly, operations executives at Goods worked to define a checklist to identify energy losses when performing preventive maintenance. At Complex Food, operations executives introduced specific tags to signal safety issues related to machinery, and wasted material, water, or energy; Medium Milk developed cards to signal potential safety or environmental risks.

In contrast, companies characterized by low levels of cross-functional executive involvement (e.g., companies with the Traditional organizational model) do not review lean bundles to ensure that they are aligned with the operations' environmental and social goals. In these companies, operations executives do not share the sustainability goals or the need to deploy sustainability cross-functionally and do not revise lean manufacturing bundles to avoid negative effects on environmental and social sustainability in operations.

These arguments can be restated in the following propositions:

P2. Cross-functional executive involvement facilitates horizontal alignment between lean manufacturing bundles and operations' environmental and social sustainability goals. 
P2a. By leveraging HRM practices to develop worker involvement toward environmental and social sustainability goals.

P2b. By defining JIT practices that are aligned with environmental and social sustainability goals.

P2c. By defining TQM and TPM practices that reinforce their alignment with environmental and social sustainability goals.

Regarding horizontal alignment between lean bundles and sustainability practices, companies characterized by the Advanced organizational model and Small Pasta are able to align TQM and TPM with environmental and social practices due to crossfunctional executive involvement, especially operations executive involvement.

Because of cross-functional executive involvement, the lean methodology and continuous improvements related to TQM and TPM are extended to environmental waste, consumption, and health and safety practices (King and Lenox, 2001). Specifically, operations executives involved in the formulation of Systems' sustainability goals highlight how lean principles can be easily aligned with pollution prevention programs. At Small Pasta and Medium Milk, operations executives, understanding the potential synergies between the lean, "no-waste" methodology and the company's goals to reduce waste and energy consumption, reviewed their TQM and TPM systems to include social and environmental practices.

In contrast, companies characterized by the Traditional organizational model, with low levels of cross-functional executive involvement, do not identify synergies and invest to a lesser extent in incremental environmental and social improvements. These companies encounter greater difficulties when attempting to identify means of reducing consumption, as they are often pushed to reduce consumption by regulations, or they develop isolated sustainability practices with little to no link to the company's sustainability deployment via operations executive involvement. Consequently, it is possible to suggest the following:

P3. Cross-functional executive involvement facilitates horizontal alignment by broadening TQM and TPM to include environmental and social practices. 
Moreover, based on the Small Pasta case, where operations executive involvement is higher than the influence of sustainability manager(s) influence, and horizontal alignment is achieved, we suggest that:

P4. Operations executive involvement plays a more important role compared to the influence of the sustainability manager(s) in fostering horizontal alignment.

Considering action alignment, companies with the Advanced organizational model and Accessory show how worker involvement enables the action alignment of lean manufacturing with environmental and social sustainability in day-to-day activities (Epstein, 2008). Worker involvement promotes awareness of and participation in sustainability issues and thus directs TQM and TPM efforts toward sustainability, employing them in a broader approach that includes social and environmental goals and practices. For example, Systems trains its workers to perform TPM to understand when machinery is not working properly, encouraging them to reduce unnecessary consumption and, consequently, reduce environmental impact.

In contrast, companies with the Traditional organizational model, which do not make substantial investments in communication and training on environmental and social issues or worker participation, do not implement lean manufacturing in a manner that allows worker behaviors to pursue social and environmental goals. Moreover, at Small Pasta, although TQM and TPM are formally aligned with environmental and social goals and practices, workers are primarily oriented toward traditional operational goals, skills, and knowledge, and they manage day-to-day activities without sufficient concern for environmental and social needs. Consequently, we arrive at the next proposition:

P5. Worker involvement positively affects the action alignment of lean manufacturing and environmental and social sustainability in day-to-day activities, resulting in higher sustainability performance.

\subsection{Theoretical contributions}

The operations management literature suggests that lean manufacturing might have both positive and negative effects on environmental and social sustainability (King and Lenox, 2001; Longoni et al., 2013) and does not provide conclusive indications on how to align them. Our research suggests that these inconclusive results are due to the lack of a theoretical perspective that considers the operations strategy deployment process. 
We analyzed the relationship between lean manufacturing and sustainability in the light of the operations strategy theory and studied the problem in terms of strategic alignment (e.g., Joshi et al., 2003). This perspective allowed us to identify the organizational model used to deploy functional strategies as a powerful tool to align lean manufacturing and sustainability.

In doing so, we contribute also to the sustainability development theory suggesting that lean manufacturing is not positively or negatively related to sustainability a priori. Building on operations strategy theory, we suggest that depending on managers' decisions and worker behavior, lean manufacturing might be a fundamental tool to improve environmental and social performance.

\subsection{Managerial implications}

Our results provide evidence to managers that the organizational model can be a crucial lever to strategically align lean manufacturing and environmental and social sustainability. The Traditional and Advanced organizational models represent two extremes. In companies with the Traditional organizational model, the company's top management claims to support improved sustainability, but sustainability is underdeveloped in operations lacking executive involvement and worker commitment. Lean manufacturing and sustainability goals and practices are addressed separately, which may create conflicts. Therefore, sustainability is not practically pursued within operations. Companies characterized by the Advanced organizational model, thanks to high cross-functional executive involvement, define a clear and enlarged lean manufacturing statement in relation to sustainability goals (vertical alignment), revise lean bundles to ensure alignment with social and environmental goals and practices in operations (horizontal alignment), and finally put this alignment into practice (action alignment) thanks to worker involvement.

Companies with Transitional organizational models show two paths to progress from misalignment to strategic alignment, suggesting the relevance of both the involvement of operations executives and the influence of individuals in sustainabilityrelated roles and the undeniable role of worker commitment. Accessory is able to align the lean manufacturing statement and company's sustainability goals (vertical alignment) thanks to the influence of sustainability manager(s) and enacts this alignment (action alignment) due to worker commitment. In contrast, Small Pasta aligns lean manufacturing and the sustainability goals in a bottom-up fashion, thanks 
to the involvement of operations executives achieving horizontal alignment. However, neither of these two companies is able to achieve full alignment because of the need to deploy both cross-functional executive involvement and worker commitment.

\section{Conclusion, limitations, and directions for future research}

The purpose of this study was to analyze the strategic (mis)alignment between lean manufacturing and environmental and social sustainability. Case study methodology and strategic alignment as matching were used to empirically derive ideal profiles of companies characterized by aligned or misaligned lean manufacturing and sustainability strategy, based on their organizational model.

However, this research suffers from some limitations that point to the need for future research. First, the strategic alignment measure is a dichotomous variable, but we do not measure it in terms of coverage, intensity, or sophistication. Second, although different industries have been analyzed, the results may not be generalizable to other contexts due to the limited number of companies involved. Future research based on broader samples of companies might test the different roles of operations executive involvement and sustainability manager(s) influence, relative to cross-functional executive involvement, on different types of alignment. In this study, the discussion around this difference is limited to single cases. Finally, this research is focused on the strategic alignment between lean manufacturing and environmental and social sustainability. Future research might explore the strategic alignment between other operations systems and sustainability and between supply chain strategies and sustainability.

\section{TABLES}

Table 1: Lean bundles and environmental sustainability

\section{Just-in-time}

- Inventory reduction allows the reduction of polluting emissions and material and energy consumption (King and Lenox, 2001).

- Setup reduction:

oallows rapid feedback from any defects, requiring less rework and resource consumption (Rothenberg et al., 2001);

oallows the production of a higher variety of products, which requires more deliveries and causes more pollution (Cusumano, 1994).

- JIT deliveries lead to smaller and more frequent deliveries causing more pollution (Venkat and Wakeland, 2006). 
- Quality circles support recycling and the reduction of scrap (Rothenberg et al., 2001).

TPM

- Reduction of breakdown labor rates, lost production, and setup time reduction reduces energy and material consumption (Katila, 2000).

\section{HRM}

- Training pushes a more proactive environmental attitude (Longoni et al., 2014).

- Teams and involvement allow for the creation of ideas and support for organizational learning for environmental development (Beard and Rees, 2000).

Table 2: Lean bundles and social sustainability

Just-in-time

- Reduced cycle time, increased workloads and work intensity, and more repetitive actions increase stress level and injuries (e.g., Askenazy, 2001).

- High work pace and intensity increase worker stress level (Conti et al., 2006).

TQM

- Quality and safety are synergistic and integrated to increase worker well-being (e.g., Herrero et al., 2002).

- Attention to quality and productivity standards reduce attention to health and safety issues (Askenazy, 2001).

TPM

- New technologies reduce breakdowns with their potential for injury (McKone et al., 2001).

- TPM develop organizational capability to identify and resolve production problems before they occur, which increases worker well-being (e.g., Brunet and New, 2003).

\section{HRM}

- Training, employee involvement, job rotation (may have positive effects by reducing repetitive activities), and working in teams (may give workers the opportunity to share issues and to provide support for each other) increase well-being (e.g., Brenner et al., 2004).

- Job rotation creates a continuous need to develop new capabilities, which could have a negative effect on worker health and safety because risks are created when performing new activities (Brenner et al., 2004).

- Incentives to improve productivity performance push workers to enhance the speed of work, increasing the risk of injuries (Kaminski, 2001).

- Employee involvement and incentives have a positive impact on worker satisfaction (Longoni et al., 2014).

- HRM practices have a positive impact on worker motivation (de Treville and Antonakis, 2006). 
Table 3: Sample selection

\begin{tabular}{|c|c|c|c|c|c|c|c|}
\hline Company & Industry & $\begin{array}{c}\text { Business Unit } \\
\text { Number of } \\
\text { Workers }\end{array}$ & $\begin{array}{c}\text { Business Unit } \\
\text { Sales } 2011\end{array}$ & $\begin{array}{l}\text { Business Unit } \\
\text { Location }\end{array}$ & $\begin{array}{c}\text { Country of } \\
\text { Origin }\end{array}$ & $\begin{array}{l}\text { Multinational } \\
\text { Company }\end{array}$ & Interviews \\
\hline Accessory & Accessories & 1000 & $600 \mathrm{mln} €$ & Italy & Italy & Yes & $\begin{array}{l}\text { - Lean expert } \\
\text { - Sustainability manager } \\
\text { - Quality manager } \\
\text { - Chief operations officer }\end{array}$ \\
\hline $\begin{array}{l}\text { Complex } \\
\text { Food }\end{array}$ & $\begin{array}{l}\text { Diversified food } \\
\text { production }\end{array}$ & 3000 & $1.343 \mathrm{mln} €$ & Italy & $\begin{array}{l}\text { United } \\
\text { Kingdom }\end{array}$ & Yes & $\begin{array}{l}\text { - HSE director } \\
\text { - Operations manager } \\
\text { - Internal communication and HRM manager } \\
\text { - Public affairs \& public relations manager } \\
\text { - Brand manager }\end{array}$ \\
\hline Goods & $\begin{array}{l}\text { Consumer } \\
\text { goods }\end{array}$ & 350 & $500 \mathrm{mln} €$ & Italy & $\begin{array}{l}\text { United } \\
\text { Stated }\end{array}$ & Yes & $\begin{array}{l}\text { - Lean erxpert } \\
\text { - Sustainability manager } \\
\text { - HRM manager }\end{array}$ \\
\hline $\begin{array}{l}\text { Medium } \\
\text { Milk }\end{array}$ & Milk and cheese & 320 & $500 \mathrm{mln} €$ & Italy & France & Yes & $\begin{array}{l}\text { - HRM, skills development, and internal } \\
\text { communication manger } \\
\text { - EHS leader } \\
\text { - Carbon master footprint manager } \\
\text { - Supply chain and operations manager } \\
\text { - Public relations manager }\end{array}$ \\
\hline Systems & $\begin{array}{l}\text { Electronic } \\
\text { components }\end{array}$ & 1600 & $600 \mathrm{mln} €$ & Germany & Germany & Yes & $\begin{array}{l}\text { - Operations manager } \\
\text { - EHS manager } \\
\text { - HRM manager }\end{array}$ \\
\hline Small Pasta & Pasta & 741 & 343 mln€ & Italy & Italy & No & $\begin{array}{l}\text { - SA } 8000 \text { coordinator } \\
\text { - HRM manager } \\
\text {-Operations manager }\end{array}$ \\
\hline Big Milk & Milk and cheese & 2000 & 900 mln€ & Italy & Italy & No & $\begin{array}{l}\text { - Operations manager } \\
\text { - HRM manager } \\
\text { - CSR manager }\end{array}$ \\
\hline Furniture & $\begin{array}{l}\text { Office furniture } \\
\text { products }\end{array}$ & 118 & $15,7 \mathrm{mln} €$ & Canada & Canada & Yes & $\begin{array}{l}\text { - VP, general manager } \\
\text { - Sustainability development manager }\end{array}$ \\
\hline Lamps & Lighting & 686 & $300 \mathrm{mln} €$ & Italy & Germany & Yes & $\begin{array}{l}\text { - HR manager } \\
\text { - Operational excellence leader } \\
\text { - Operations manager } \\
\text { - EHS \& quality leader }\end{array}$ \\
\hline Veggie & Vegetables & 439 & $178,5 \mathrm{mln} €$ & Italy & France & Yes & $\begin{array}{l}\text { - Operations and supply chain manager } \\
\text { - HRM manager } \\
\text { - Marketing manager }\end{array}$ \\
\hline
\end{tabular}


Table 4: Cross-functional executive involvement and workers involvement operationalization

\begin{tabular}{|c|c|c|c|}
\hline $\begin{array}{l}\text { Construct } \\
\text { Measured }\end{array}$ & & Description & OPERATIONALIZATON \\
\hline \multirow[t]{2}{*}{$\begin{array}{l}\text { Cross- } \\
\text { functional } \\
\text { executive } \\
\text { involvement }\end{array}$} & $\begin{array}{l}\text { Sustainability } \\
\text { manager(s) } \\
\text { influence }\end{array}$ & $\begin{array}{l}\text { Level of influence of sustainability-related } \\
\text { roles in the decision-making process of } \\
\text { operations strategy (i.e., lean } \\
\text { manufacturing system) formulation } \\
\text { (adapted from Papke-Shilds and Malhotra, } \\
\text { 2001) }\end{array}$ & $\begin{array}{l}\text { - Sustainability manager(s) in operations are not involved in the decision making process (e.g., only } \\
\text { supervision) (1); } \\
\text { - Sustainability manager (s) in operations are seldom involved in the decision making process (2); } \\
\text { - Sustainability manager(s) in operations are often involved in the decision making process (3). }\end{array}$ \\
\hline & $\begin{array}{l}\text { Operations } \\
\text { executive } \\
\text { involvement }\end{array}$ & $\begin{array}{l}\text { Level of operations executives involvement } \\
\text { in the company’s sustainability goals } \\
\text { formulation (adapted from Papke-Shilds } \\
\text { and Malhotra, 2001) }\end{array}$ & $\begin{array}{l}\text { - Operations executives are not involved in the company’s sustainability goals formulation (1); } \\
\text { - Operations executives are } \underline{\text { seldom involved }} \text { in the company’s sustainability goals formulation (2); } \\
\text { - Operations executives are often involved in the company's sustainability goals formulation (3). }\end{array}$ \\
\hline \multirow[t]{2}{*}{$\begin{array}{l}\text { Worker } \\
\text { involvement }\end{array}$} & $\begin{array}{l}\text { Worker } \\
\text { awareness }\end{array}$ & $\begin{array}{l}\text { Mechanisms in place to increase } \\
\text { awareness of operations workers about } \\
\text { sustainability practices and goals (Bansal } \\
\text { and Roth, 2000; Epstein, 2008) }\end{array}$ & $\begin{array}{l}\text { - Sustainability strategies are not shared with workers (1); } \\
\text { - Sustainability strategies are communicated to workers (e.g., in companies events, newsletters) (2); } \\
\text { - Workers receive formal training about sustainability strategies (3). }\end{array}$ \\
\hline & $\begin{array}{l}\text { Worker } \\
\text { participation }\end{array}$ & $\begin{array}{l}\text { Mechanisms in place to allow an active } \\
\text { worker involvement in sustainability } \\
\text { development within operations (Epstein, } \\
\text { 2008) }\end{array}$ & $\begin{array}{l}\text { - No suggestions by workers are collected (1); } \\
\text { - Suggestions by workers are informally collected (2); } \\
\text { - Suggestions by workers are formally collected (3). }\end{array}$ \\
\hline
\end{tabular}


Table 5: Strategic alignment operationalization (adapted from Gratton and Truss, 2003)

\begin{tabular}{|c|c|c|}
\hline $\begin{array}{l}\text { Construct } \\
\text { Measured }\end{array}$ & Description & OPERATIONALIZATON \\
\hline $\begin{array}{l}\text { Vertical } \\
\text { alignment }\end{array}$ & $\begin{array}{l}\text { Alignment of the lean manufacturing } \\
\text { statement with the company's } \\
\text { sustainability goals }\end{array}$ & $\begin{array}{l}\text { There is a clear statement of lean manufacturing and how it supports the environmental and } \\
\text { social goals: } \\
-\underline{\text { Yes }}\end{array}$ \\
\hline \multirow[t]{2}{*}{$\begin{array}{l}\text { Horizontal } \\
\text { alignment }\end{array}$} & $\begin{array}{l}\text { Alignment between each lean bundle } \\
\text { and sustainability-related goal in } \\
\text { operations }\end{array}$ & 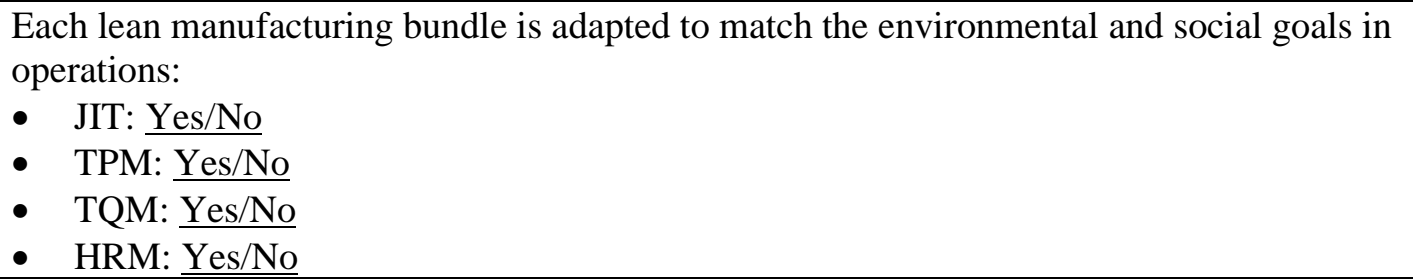 \\
\hline & $\begin{array}{l}\text { Alignment between each lean bundle } \\
\text { and sustainability practice in } \\
\text { operations }\end{array}$ & $\begin{array}{l}\text { Each lean manufacturing bundle is adapted to match the environmental and social practices } \\
\text { adopted within operations: } \\
\text { - JIT: } \underline{\text { Yes/No }} \\
\text { - TPM: } \underline{\text { Yes/No }} \\
\text { - TQM: } \underline{\text { Yes/No }} \\
\text { - HRM: } \underline{\text { Yes/No }}\end{array}$ \\
\hline $\begin{array}{l}\text { Action } \\
\text { alignment }\end{array}$ & $\begin{array}{l}\text { Alignment of lean manufacturing } \\
\text { bundles with sustainability goals and } \\
\text { practices in the behaviors of day-to- } \\
\text { day activities in operations }\end{array}$ & $\begin{array}{l}\text { Behaviors are changed so that lean manufacturing bundles are enacted in alignment with } \\
\text { environmental and social sustainability goals and practices: } \\
\text { - Yes: Behaviors in day-to-day activities are changed to foster lean manufacturing and } \\
\text { sustainability. } \\
\text { - No: Behaviors in day-to-day activities are not changed; the traditional way of working is } \\
\text { performed. }\end{array}$ \\
\hline
\end{tabular}


Table 6: Sustainability performance operationalization

\begin{tabular}{|c|c|c|}
\hline $\begin{array}{l}\text { Constructs } \\
\text { Measured }\end{array}$ & Description & OPERATIONALIZATON \\
\hline $\begin{array}{l}\text { Economical } \\
\text { sustainability }\end{array}$ & $\begin{array}{l}\text { Financial performance and cash flow } \\
\text { profitability related to company's } \\
\text { investments: ROI and ROA } \\
\text { (Corbett, 2009) }\end{array}$ & $\begin{array}{l}\text { - Above average (5): mean of each metric was } 2 \text { or more standard deviations above sample average; } \\
\text { - Somewhat above average (4): mean of each metric was } 1 \text { standard deviation above sample average; } \\
\text { - Average (3): mean of each metric was the same as sample average; } \\
\text { - Somewhat below average (2): mean of each metric was } 1 \text { standard deviation below sample average; } \\
\text { - Below average (1): mean of each metric was } 1 \text { or more standard deviations below sample average. }\end{array}$ \\
\hline $\begin{array}{l}\text { Environmental } \\
\text { sustainability }\end{array}$ & $\begin{array}{l}\text { - Material usage: \% material usage } \\
\text { reduction; } \\
\text { - Energy consumption: \% energy usage } \\
\text { reduction; } \\
\text { - Water consumption: \% water usage } \\
\text { reduction; } \\
\text { - Waste production: \% waste reduction; } \\
\text { - Pollutant emissions: \% CO } \text { emission }_{2} \\
\text { reduction. } \\
\text { (Ranganathan, 1998; Corbett, 2009) }\end{array}$ & $\begin{array}{l}\text { - Above average (5): mean of each metric was } 2 \text { or more standard deviations above sample average; } \\
\text { - Somewhat above average (4): mean of each metric was } 1 \text { standard deviation above sample average; } \\
\text { - Average (3): mean of each metric was the same as sample average; } \\
\text { - Somewhat below average (2): mean of each metric was } 1 \text { standard deviation below sample average; } \\
\text { - Below average (1): mean of each metric was } 1 \text { or more standard deviations below sample average. }\end{array}$ \\
\hline $\begin{array}{l}\text { Social } \\
\text { sustainability }\end{array}$ & $\begin{array}{l}\text { - Number of injuries; } \\
\text { - Number of working hours lost due to } \\
\text { illness; } \\
\text { - Worker satisfaction (McKenzie, 2004; } \\
\text { Jennings and Entine, 1999) }\end{array}$ & $\begin{array}{l}\text { - Above average (5): mean of each metric was } 2 \text { or more standard deviations above sample average; } \\
\text { - } \text { Somewhat above average (4): mean of each metric was } 1 \text { standard deviation above sample average; } \\
\text { - Average (3): mean of each metric was the same as sample average; } \\
\text { - } \text { Somewhat below average (2): mean of each metric was } 1 \text { standard deviation below sample average; } \\
\text { - Below average (1): mean of each metric was } 1 \text { or more standard deviations below sample average. }\end{array}$ \\
\hline $\begin{array}{l}\text { Overall } \\
\text { sustainability } \\
\text { performance }\end{array}$ & \multicolumn{2}{|c|}{ Average of the performance achieved in the different sustainability dimensions } \\
\hline
\end{tabular}


Table 7: Cross-functional executive involvement assessment

\begin{tabular}{|c|c|c|c|c|c|c|c|c|c|c|}
\hline \multirow{2}{*}{$\begin{array}{l}\text { Groups } \\
\text { Companies } \\
\end{array}$} & \multicolumn{4}{|c|}{ Advanced organisational model } & \multicolumn{2}{|c|}{$\begin{array}{c}\begin{array}{c}\text { Transitional organisational } \\
\text { model }\end{array} \\
\end{array}$} & \multicolumn{4}{|c|}{ Traditional organisational model } \\
\hline & $\begin{array}{l}\text { Complex } \\
\text { Food }\end{array}$ & Goods & $\begin{array}{l}\text { Medium } \\
\text { Milk }\end{array}$ & Systems & Accessory & Small Pasta & Big Milk & Furniture & Lamps & Veggie \\
\hline $\begin{array}{l}\text { Sustainability } \\
\text { manager(s) } \\
\text { influence }\end{array}$ & $\begin{array}{c}\text { Often } \\
\text { involved in } \\
\text { DM (3) }\end{array}$ & $\begin{array}{c}\text { Often } \\
\text { involved in } \\
\text { DM (3) }\end{array}$ & $\begin{array}{c}\text { Often } \\
\text { involved in } \\
\text { DM (3) }\end{array}$ & $\begin{array}{c}\text { Often } \\
\text { involved in } \\
\text { DM (3) }\end{array}$ & $\begin{array}{c}\text { Often } \\
\text { involved in } \\
\text { DM (3) }\end{array}$ & $\begin{array}{c}\text { Seldom } \\
\text { involved in } \\
\text { DM (2) }\end{array}$ & $\begin{array}{c}\text { Not } \\
\text { involved in } \\
\text { DM (1) }\end{array}$ & $\begin{array}{c}\text { Seldom } \\
\text { involved in } \\
\text { DM (2) }\end{array}$ & $\begin{array}{l}\text { Not involved } \\
\text { in DM (1) }\end{array}$ & $\begin{array}{c}\text { Not } \\
\text { involved } \\
\text { in DM (1) } \\
\end{array}$ \\
\hline $\begin{array}{l}\text { Operations } \\
\text { executives } \\
\text { involvement }\end{array}$ & $\begin{array}{c}\text { Often } \\
\text { involved (3) }\end{array}$ & $\begin{array}{c}\text { Often } \\
\text { involved (3) }\end{array}$ & $\begin{array}{c}\text { Often } \\
\text { involved (3) }\end{array}$ & $\begin{array}{c}\text { Often } \\
\text { involved (3) }\end{array}$ & $\begin{array}{c}\text { Seldom } \\
\text { involved (2) }\end{array}$ & $\begin{array}{c}\text { Often } \\
\text { involved (3) }\end{array}$ & $\begin{array}{c}\text { Not } \\
\text { involved (1) }\end{array}$ & $\begin{array}{c}\text { Not } \\
\text { involved (1) }\end{array}$ & $\begin{array}{l}\text { Not involved } \\
\text { (1) }\end{array}$ & $\begin{array}{c}\text { Seldom } \\
\text { involved } \\
(1) \\
\end{array}$ \\
\hline Overall level & 3 & 3 & 3 & 3 & 2.5 & 2.5 & 1 & 1.5 & 1 & 1 \\
\hline
\end{tabular}

Table 8: Worker involvement assessment

\begin{tabular}{|c|c|c|c|c|c|c|c|c|c|c|}
\hline \multirow{2}{*}{$\begin{array}{l}\text { Groups } \\
\text { Companies }\end{array}$} & \multicolumn{4}{|c|}{ Advanced organisational model } & \multicolumn{2}{|c|}{$\begin{array}{c}\text { Transitional organisational } \\
\text { model }\end{array}$} & \multicolumn{4}{|c|}{ Traditional organisational model } \\
\hline & Complex Food & Goods & $\begin{array}{l}\text { Medium } \\
\text { Milk }\end{array}$ & Systems & Accessory & Small Pasta & Big Milk & Furniture & Lamps & Veggie \\
\hline $\begin{array}{l}\text { Workers } \\
\text { awareness }\end{array}$ & Training (3) & Training (3) & $\begin{array}{c}\text { Communicati } \\
\text { on (2) }\end{array}$ & Training (3) & Trained (3) & $\begin{array}{l}\text { Communicati } \\
\text { on (2) }\end{array}$ & $\begin{array}{l}\text { Not shared } \\
\text { (1) }\end{array}$ & $\begin{array}{l}\text { Not shared } \\
\text { (1) }\end{array}$ & $\begin{array}{l}\text { Not shared } \\
\text { (1) }\end{array}$ & $\begin{array}{l}\text { Not shared } \\
\text { (1) }\end{array}$ \\
\hline $\begin{array}{l}\text { Workers } \\
\text { participation }\end{array}$ & $\begin{array}{l}\text { Formally } \\
\text { collected (3) }\end{array}$ & $\begin{array}{l}\text { Formally } \\
\text { collected (3) }\end{array}$ & $\begin{array}{l}\text { Formally } \\
\text { collected (3) }\end{array}$ & $\begin{array}{l}\text { Formally } \\
\text { collected (3) }\end{array}$ & $\begin{array}{l}\text { Informally } \\
\text { collected (2) }\end{array}$ & $\begin{array}{l}\text { Informally } \\
\text { collecetd (2) }\end{array}$ & $\begin{array}{c}\text { Not } \\
\text { collected (1) }\end{array}$ & $\begin{array}{c}\text { Not } \\
\text { collected (1) }\end{array}$ & $\begin{array}{c}\text { Not } \\
\text { collected (1) }\end{array}$ & $\begin{array}{c}\text { Not } \\
\text { collected } \\
(1)\end{array}$ \\
\hline Overall level & 3 & 3 & 2.5 & 3 & 2.5 & 2 & 1 & 1 & 1 & 1 \\
\hline
\end{tabular}


Table 9: Vertical alignment assessment

\begin{tabular}{|c|c|c|c|c|}
\hline Groups & Companies & $\begin{array}{c}\text { Lean statement - } \\
\text { Environmental Goals }\end{array}$ & $\begin{array}{l}\text { Lean statement - Social } \\
\text { goals }\end{array}$ & Vertical alignment index \\
\hline \multirow{4}{*}{$\begin{array}{c}\text { Advanced } \\
\text { organisational model }\end{array}$} & Complex Food & 1 & 1 & 2 \\
\hline & Goods & 1 & 1 & 2 \\
\hline & Medium Milk & 1 & 1 & 2 \\
\hline & Systems & 1 & 1 & 2 \\
\hline \multirow{2}{*}{$\begin{array}{c}\text { Transitional } \\
\text { organisational model }\end{array}$} & Accessory & 1 & 1 & 2 \\
\hline & Small Pasta & 0 & 0 & 0 \\
\hline \multirow{4}{*}{$\begin{array}{c}\text { Traditional } \\
\text { organisational model }\end{array}$} & Big Milk & 0 & 0 & 0 \\
\hline & Furniture & 0 & 0 & 0 \\
\hline & Lamps & 0 & 0 & 0 \\
\hline & Veggie & 0 & 0 & 0 \\
\hline
\end{tabular}

Table 10: Horizontal alignment assessment

\begin{tabular}{|c|c|c|c|c|c|c|c|c|c|c|c|c|c|c|c|c|c|c|}
\hline \multirow[b]{2}{*}{ Groups } & \multirow[b]{2}{*}{ Companies } & \multicolumn{4}{|c|}{$\begin{array}{c}\text { Lean Bundles - } \\
\text { Environmental goals in } \\
\text { operations }\end{array}$} & \multicolumn{4}{|c|}{$\begin{array}{c}\text { Lean Bundles - } \\
\text { Environmental practices }\end{array}$} & \multicolumn{4}{|c|}{$\begin{array}{c}\text { Lean Bundles -Social goals } \\
\text { in operations }\end{array}$} & \multicolumn{4}{|c|}{$\begin{array}{c}\text { Lean Bundles -Social } \\
\text { practices }\end{array}$} & \multirow[b]{2}{*}{$\begin{array}{c}\text { Horizontal } \\
\text { alignment } \\
\text { index }\end{array}$} \\
\hline & & JIT & $T P M$ & $T Q M$ & $H R M$ & JIT & $T P M$ & $T Q M$ & $H R M$ & JIT & $T P M$ & $T Q M$ & $H R M$ & JIT & TPM & $T Q M$ & $H R M$ & \\
\hline \multirow{4}{*}{$\begin{array}{c}\text { Advanced } \\
\text { organisational } \\
\text { model }\end{array}$} & $\begin{array}{l}\text { Complex } \\
\text { Food }\end{array}$ & 1 & 1 & 1 & 1 & 1 & 1 & 1 & 1 & 1 & 1 & 1 & 1 & 1 & 1 & 1 & 1 & 16 \\
\hline & Goods & 1 & 1 & 1 & 1 & 1 & 1 & 1 & 1 & 1 & 1 & 1 & 1 & 1 & 1 & 1 & 1 & 16 \\
\hline & $\begin{array}{c}\text { Medium } \\
\text { Milk }\end{array}$ & 1 & 1 & 1 & 1 & 1 & 1 & 1 & 1 & 1 & 1 & 1 & 1 & 1 & 1 & 1 & 1 & 16 \\
\hline & Systems & 1 & 1 & 1 & 1 & 1 & 1 & 1 & 1 & 1 & 1 & 1 & 1 & 1 & 1 & 1 & 1 & 16 \\
\hline \multirow{2}{*}{$\begin{array}{c}\text { Transitional } \\
\text { organisational } \\
\text { model }\end{array}$} & Accessory & 0 & 0 & 0 & 0 & 0 & 0 & 0 & 0 & 0 & 0 & 0 & 0 & 0 & 0 & 0 & 0 & 0 \\
\hline & $\begin{array}{l}\text { Small } \\
\text { Pasta }\end{array}$ & 0 & 1 & 1 & 1 & 0 & 1 & 1 & 1 & 0 & 1 & 1 & 1 & 0 & 1 & 1 & 1 & 12 \\
\hline \multirow{4}{*}{$\begin{array}{c}\text { Traditional } \\
\text { organisational } \\
\text { model }\end{array}$} & Big Milk & 0 & 0 & 0 & 0 & 0 & 0 & 0 & 0 & 0 & 0 & 0 & 0 & 0 & 0 & 0 & 0 & 0 \\
\hline & Furniture & 0 & 0 & 0 & 0 & 0 & 0 & 0 & 0 & 0 & 0 & 0 & 0 & 0 & 0 & 0 & 0 & 0 \\
\hline & Lamps & 0 & 0 & 0 & 0 & 0 & 0 & 0 & 0 & 0 & 0 & 0 & 0 & 0 & 0 & 0 & 0 & 0 \\
\hline & Veggie & 0 & 0 & 0 & 0 & 0 & 0 & 0 & 0 & 0 & 0 & 0 & 0 & 0 & 0 & 0 & 0 & 0 \\
\hline
\end{tabular}


Table 11: Action alignment assessment

\begin{tabular}{|c|c|c|c|c|c|c|c|c|c|c|}
\hline \multirow[b]{2}{*}{ Groups } & \multirow[b]{2}{*}{ Companies } & \multicolumn{4}{|c|}{$\begin{array}{c}\text { Lean action - Environmental } \\
\text { strategy }\end{array}$} & \multicolumn{4}{|c|}{ Lean Action - Social strategy } & \multirow[b]{2}{*}{ Action alignment index } \\
\hline & & JIT & $T P M$ & $T Q M$ & $H R M$ & JIT & $T P M$ & TQM & $H R M$ & \\
\hline \multirow{4}{*}{$\begin{array}{c}\text { Advanced } \\
\text { organisational model }\end{array}$} & Complex Food & 1 & 1 & 1 & 1 & 1 & 1 & 1 & 1 & 8 \\
\hline & Goods & 1 & 1 & 1 & 1 & 1 & 1 & 1 & 1 & 8 \\
\hline & Medium Milk & 1 & 1 & 1 & 1 & 1 & 1 & 1 & 1 & 8 \\
\hline & Systems & 1 & 1 & 1 & 1 & 1 & 1 & 1 & 1 & 8 \\
\hline \multirow{2}{*}{$\begin{array}{c}\text { Transitional } \\
\text { organisational model }\end{array}$} & Accessory & 1 & 1 & 1 & 1 & 1 & 1 & 1 & 1 & 8 \\
\hline & Small Pasta & 0 & 0 & 0 & 1 & 0 & 0 & 0 & 1 & 2 \\
\hline \multirow{4}{*}{$\begin{array}{c}\text { Traditional } \\
\text { organisational model }\end{array}$} & Big Milk & 0 & 0 & 0 & 0 & 0 & 0 & 0 & 0 & 0 \\
\hline & Furniture & 0 & 0 & 0 & 0 & 0 & 0 & 0 & 0 & 0 \\
\hline & Lamps & 0 & 0 & 0 & 0 & 0 & 0 & 0 & 0 & 0 \\
\hline & Veggie & 0 & 0 & 0 & 0 & 0 & 0 & 0 & 0 & 0 \\
\hline
\end{tabular}

Table 12: Sustainability performance assessment

\begin{tabular}{|c|c|c|c|c|c|c|c|c|c|c|}
\hline \multirow{2}{*}{$\begin{array}{l}\text { Groups } \\
\text { Companies }\end{array}$} & \multicolumn{4}{|c|}{ Advanced organisational model } & \multicolumn{2}{|c|}{$\begin{array}{c}\text { Transitional organisational } \\
\text { model }\end{array}$} & \multicolumn{4}{|c|}{ Traditional organisational model } \\
\hline & Complex Food & Goods & Medium Milk & Systems & Accessory & Small Pasta & Big Milk & Furniture & Lamps & Veggie \\
\hline Economic & Average (3) & $\begin{array}{l}\text { Somewhat } \\
\text { above (4) }\end{array}$ & Average (3) & Average (3) & Above (5) & Below (1) & Below (1) & $\begin{array}{l}\text { Somewhat } \\
\text { above (4) }\end{array}$ & $\begin{array}{l}\text { Somewhat } \\
\text { below (2) }\end{array}$ & Below (1) \\
\hline Environmetal & Above (5) & $\begin{array}{l}\text { Somewhat } \\
\text { above (4) }\end{array}$ & Above (5) & $\begin{array}{l}\text { Somewhat } \\
\text { above (4) }\end{array}$ & $\begin{array}{l}\text { Somewhat } \\
\text { below (2) }\end{array}$ & $\begin{array}{l}\text { Somewhat } \\
\text { above (4) }\end{array}$ & $\begin{array}{l}\text { Somewhat } \\
\text { below (2) }\end{array}$ & $\begin{array}{l}\text { Somewhat } \\
\text { below (2) }\end{array}$ & Average (3) & $\begin{array}{l}\text { Somewhat } \\
\text { below (2) }\end{array}$ \\
\hline Social & Above (5) & $\begin{array}{l}\text { Somewhat } \\
\text { above (4) }\end{array}$ & Above (5) & $\begin{array}{l}\text { Somewhat } \\
\text { above (4) }\end{array}$ & Above (5) & Average (3) & Below (1) & $\begin{array}{l}\text { Somewhat } \\
\text { below (2) }\end{array}$ & Average (3) & Below (1) \\
\hline Overall & 4.3 & 4 & 4.3 & 3.6 & 4 & 2.6 & 1.3 & 2.6 & 2.6 & 1.3 \\
\hline
\end{tabular}




\section{Appendix A: Lean manufacturing adoption}

Appendix A presents the operationalization and the assessment of the lean manufacturing adoption.

Table A.1: Lean manufacturing operationalization

\begin{tabular}{|c|l|}
\hline \multicolumn{1}{|c|}{ Constructs } & \multicolumn{1}{c|}{ OPERATIONALIZATON } \\
\hline JIT, TQM and HRM & $\begin{array}{l}\bullet \text { Extensively: Full/meaningful adoption of related practices } \\
\bullet \text { Some: Some adoption of related practices } \\
\bullet \text { No: No meaningful adoption of related practices }\end{array}$ \\
\hline
\end{tabular}

Table A.2: Lean manufacturing assessment

\begin{tabular}{|l|c|c|c|c|}
\hline & JIT & TQM & TPM & \\
\hline Complex Food & Medium & High & High & High \\
\hline Goods & High & High & High & High \\
\hline Medium Milk & Medium & High & High & High \\
\hline Systems & High & Medium & Medium & High \\
\hline Accessory & Medium & High & Medium & High \\
\hline Small Pasta & Medium & High & High & High \\
\hline Big Milk & Medium & High & High & Medium \\
\hline Lamps & Medium & Medium & High & Medium \\
\hline Furniture & High & High & High & Medium \\
\hline Veggie & Medium & High & Medium & Medium \\
\hline
\end{tabular}




\section{Appendix B: Sustainability goals and practices}

Appendix B presents the operationalization and the assessment of the sustainability goals and practices.

Table B1: Sustainability goals and practices operationalization

\begin{tabular}{|l|l|}
\hline \multicolumn{1}{|c|}{ Construct } & \multicolumn{1}{c|}{ OPERATIONALIZATION } \\
\hline $\begin{array}{l}\text { Company } \\
\text { sustainability goals }\end{array}$ & $\begin{array}{l}\bullet \text { High holistic view: goals related to all three sustainability pillars at the company level } \\
\text { Medium holistic view: goals related to environmental and economic sustainability or environmental and social sustainability at the company } \\
\text { level } \\
\bullet \text { Low holistic view: goals related only to economic sustainability at the company level }\end{array}$ \\
\hline $\begin{array}{l}\text { Operations } \\
\text { sustainability goals }\end{array}$ & $\begin{array}{l}\bullet \text { High holistic view: goals related to all three sustainability pillars at the operations level } \\
\text { Medium holistic view: goals related to environmental and economic sustainability or environmental and social sustainability at the operations } \\
\text { level } \\
\bullet \text { Low holistic view: goals related only to economic sustainability at the operations level }\end{array}$ \\
\hline $\begin{array}{l}\text { Environmental } \\
\text { practices }\end{array}$ & $\begin{array}{l}\bullet \text { Extensively: Full/meaningful adoption of environmental practices } \\
\bullet \text { Some: Some adoption of environmental practices } \\
\bullet \text { No: No meaningful adoption of environmental practices }\end{array}$ \\
\hline Social practices & $\begin{array}{l}\bullet \text { Extensively: Full/meaningful adoption of social practices } \\
\text { Some: Some adoption of social practices } \\
\text {-No: No meaningful adoption of social practices }\end{array}$ \\
\hline
\end{tabular}

Table B2: Sustainability goals and practices assessment

\begin{tabular}{|c|c|c|c|c|c|c|c|c|c|c|}
\hline & Complex Food & Goods & Medium Milk & Systems & Accessory & $\begin{array}{l}\text { Small } \\
\text { Pasta }\end{array}$ & Big Milk & Lamps & Furniture & Veggie \\
\hline $\begin{array}{l}\text { Company sustainability } \\
\text { goals }\end{array}$ & High Holistic & High Holistic & High Holistic & $\begin{array}{c}\text { High } \\
\text { Holistic }\end{array}$ & $\begin{array}{c}\text { High } \\
\text { Holistic }\end{array}$ & $\begin{array}{c}\text { High } \\
\text { Holistic }\end{array}$ & $\begin{array}{c}\text { High } \\
\text { Holistic }\end{array}$ & $\begin{array}{c}\text { High } \\
\text { Holistic }\end{array}$ & $\begin{array}{c}\text { High } \\
\text { Holistic }\end{array}$ & $\begin{array}{c}\text { High } \\
\text { Holistic }\end{array}$ \\
\hline $\begin{array}{l}\text { Operations sustainability } \\
\text { goals }\end{array}$ & High Holistic & High Holistic & High Holistic & $\begin{array}{c}\text { High } \\
\text { Holistic }\end{array}$ & $\begin{array}{l}\text { High } \\
\text { Holistic }\end{array}$ & $\begin{array}{l}\text { High } \\
\text { Holistic }\end{array}$ & $\begin{array}{c}\text { High } \\
\text { Holistic }\end{array}$ & $\begin{array}{l}\text { High } \\
\text { Holistic }\end{array}$ & $\begin{array}{l}\text { High } \\
\text { Holistic }\end{array}$ & $\begin{array}{l}\text { High } \\
\text { Holistic }\end{array}$ \\
\hline Environmental practices & Extensively & Extensively & Extensively & Extensively & Some & Some & Some & Some & Some & Some \\
\hline Social practices & Extensively & Extensively & Extensively & Extensively & Extensively & Some & Some & Some & Some & Some \\
\hline
\end{tabular}


